\title{
Agranulocytosis during malaria prophylaxis with Maloprim (pyrimethamine and
}

\author{
F. BOOTH \\ B.Sc., M.B., M.R.C.P. \\ L. C. BARKER \\ M.B., M.R.C.P. \\ C. J. BARTON \\ M.A., M.B., M.R.C.P., M.R.C.Path. \\ R. B. NAIK \\ M.B., M.R.C.P. \\ Departments of Medicine and Haematology, Royal Berkshire Hospital, Reading RGI 5AN
}

\begin{abstract}
Summary
A case of agranulocytosis during malaria prophylaxis with Maloprim (pyrimethamine and dapsone) is described. At the recommended dose of one tablet weekly this is apparently a rare occurrence but highlights one of the hazards in a changing climate of malarial prophylaxis in which the use of Maloprim is increasing.
\end{abstract}

KEY WORDS: malaria, pyrimethamine and dapsone, agranulocytosis.

\section{Introduction}

The increasing emergence of chloroquine-resistant Plasmodium falciparum strains has led to a change in the pattern of prescribing for malaria prophylaxis. Two combination agents, Maloprim (pyrimethamine $12.5 \mathrm{mg}$ and dapsone $100 \mathrm{mg}$ ) and Fansidar (pyrimethamine $25 \mathrm{mg}$ and sulfadoxine $500 \mathrm{mg}$ ) are now recommended for use in chloroquine-resistant $P$. falciparum areas (Communicable Disease Report 52, 1982). We describe a case of agranulocytosis which occurred in association with Maloprim.

\section{Case report}

A 52-year-old man presented to his general practitioner within a few days of returning from a holiday in New Zealand. He had suffered general malaise for 5 days, sore throat and perianal tenderness for 3 days, and fever with rigors, nausea, diarrhoea and cough for $48 \mathrm{hr}$. A blood count revealed his haemoglobin to be $13.7 \mathrm{~g} / \mathrm{dl}$, white cell count $0.27 \times 10^{9} / 1$ and platelets $333 \times 10^{9} / 1$. No granulocytes could be seen on the blood film.

The patient was admitted to hospital within hours

Correspondence: Dr F. Booth, Haematology Department, Royal Berkshire Hospital, Reading RG 1 5AN, Berks. of the blood test. He was severely prostrated, febrilep and had a spreading perianal cellulitis. In addition he had marked pharyngitis and an inflamed area in the second toe cleft of the left foot. There was right-sided pneumonia and abdominal distension associated with paralytic ileus. Blood cultures subsequently grew Escherichia coli and a $\beta$-haemolytic streptococe cus of Lancefield group B. Bone marrow aspirate? revealed an absence of granulocytes and suppressionno of erythropoiesis but preservation of megakaryop $\mathrm{i}_{+}^{+}$ esis. Abnormal laboratory findings included modêro ately raised bilirubin and liver enzyme concentra tions.

The patient was nursed in protective isolation. $\mathrm{H}$ was treated initially with intravenous gentamicin® cefuroxime and metranidazole. In the light of the antibiotic sensitivities of the cultured organisms these were later changed to netilmicin, cefotoxime ands benzyl penicillin. He received oral nystatin and chlorhexidine washes to the whole body. Folic acid supplements were given but steroids were not used 3 . The patient remained severely ill for several dayso From the second day antibiotic therapy was supple mented with daily granulocyte transfusions (consisto ing of buffy coat preparations from ten donors on each occasion). Seven days after admission his white cell count was still very low but he began to improves clinically and his fever settled. A repeat bone marrow aspiration on the following day showed early return of granulocyte activity. Thereafter he improved? steadily over the next 2 weeks. His granulocyte counf increased to supranormal levels associated with localization and early resolution of the cellulitice areas.

The only drug taken by the patient within $\stackrel{0}{\delta}$ months of admission was Maloprim, which he had? been prescribed as antimalarial prophylaxis duringo his visit to New Zealand, travelling via Abu Dhabio Singapore and Malaysia. He had taken a dose of one 
tablet weekly for 8 weeks, the last tablet 5 days before entry to hospital.

\section{Discussion}

There has been considerable debate concerning prophylaxis against malaria in areas of $P$. falciparum chloroquine-resistance (Bruce-Chwatt, 1982; Onori, 1982). With increasing use of the combination preparations Maloprim and Fansidar reports of serious adverse reactions to these agents are appearing. Several reports of serious reactions to Fansidar (pyrimethamine-sulfadoxine) have been published recently, (Olsen, Loft and Christensen, 1982; Whitfield, 1982). These have been of a similar nature to the reactions observed with other sulphonamidecontaining preparations particularly when formulated with an additional inhibitor of folate metabolism. With regard to agranulocytosis, the relative importance of pyrimethamine, an antifolate agent capable of causing megaloblastic anaemia, is debatable. Maloprim contains a reduced amount of pyrimethamine compared to Fansidar but dapsone is known to cause agranulocytosis on occasion. Nevertheless we have found only one report of this serious side effect in a patient who had been taking Maloprim at the manufacturer's recommended onceweekly dosage but who was also receiving other drugs and who died within $\mathbf{4 8} \mathrm{hr}$ of admission (Rée, 1983). Herbertson and Robson (1983) observed a case of severe neutropenia in a patient who had been taking what was thought to be Maloprim once a week as prophylaxis against malaria but the nature of the preparation could not be confirmed. Other reports of agranulocytosis associated with Maloprim have been in patients taking a higher dose of one tablet twice a week which may significantly increase the incidence of this reaction (Friman et al., 1983; Whitehead and Geary, 1983).

Our case occurred in the United Kingdom following the patient's visit to New Zealand. Maloprim had been taken at the recommended dosage of one tablet weekly simply to cover passage through malarious areas in transit. With increasing use of the drug more cases such as ours can be expected and are likely to further fuel the debate concerning the safety of effective malarial prophylaxis.

\section{References}

BRUCE-ChWATT, L.J. (1982) Chemoprophylaxis of malaria in Africa: the spent 'magic bullet'. British Medical Journal, 285, 674. COMMUNICABLE DISEASES RePORT 82/52 (1982) Malaria prophylaxis. Public Health Laboratory Services (From P.H.L.S. Malaria Reference Laboratory, London School of Hygiene and Tropical Medicine.)

Friman, G., Nyström-Rosander, C., Jonsell, G., BJorkman, A., LEKÅs, G. \& SVENDSRUP, B. (1983) Agranulocytosis associated with malaria prophylaxis with Maloprim. British Medical Journal, 286, 1244.

HERbERTSON, M. \& RobSON, R.H. (1983) Agranulocytosis associated with Maloprim. British Medical Journal, 286, 1515.

OlSEN, V.V., LOFT, S. \& Christensen, K.D. (1982) Serious reactions during malaria prophylaxis with pyrimethamine-sulfadoxine. Lancet, ii, 994.

ONORI, E. (1982) Chemoprophylaxis of malaria in Africa. British Medical Journal, 285, 1202.

RÉE, G.H. (1983) Chemophrophylaxis of malaria in Africa. British Medical Journal, 286, 562.

WhiteheAD, S. \& GeARY, C.G. (1983) Agranulocytosis associated with Maloprim. British Medical Journal, 286, 1515.

WhITFIELD, D. (1982) Presumptive fatality due to pyrimethaminesulfadoxine. Lancet, ii, 1272.

(Accepted 5 July 1983) 